\title{
ERRATUM
}

\section{MicroRNA-30a-5p in the prefrontal cortex controls the transition from moderate to excessive alcohol consumption}

E Darcq, V Warnault, K Phamluong, GM Besserer, F Liu and D Ron

Molecular Psychiatry (2015) 20, 1261; doi:10.1038/mp.2014.155; published online 11 November 2014

Correction to: Molecular Psychiatry (2014); advance online publication 21 October 2014; doi: 10.1038/mp.2014.120
As the result of an editing error, the second author was incorrectly shown as being affiliated with McGill University. V Warnault is affiliated only with the University of California, San Francisco. The publisher regrets the error. 